\title{
AUTONOMOUS LITERARY EDUCATION THROUGH THE CREATION OF VIDEO
}

\author{
L. Fernandes ${ }^{1}$, L.R. Oliveira ${ }^{2}$ \\ ${ }^{1}$ High School Camilo Castelo Branco, Vila Nova de Famalicão (PORTUGAL) \\ ${ }^{2}$ Universidade do Minho, Braga (PORTUGAL)
}

\begin{abstract}
The study has two objectives that complement each other, and it describes a pedagogic experience carried out in a Portuguese Public High School, within the Portuguese language subject. The first objective of this research aims to develop an autonomous learning approach for the Portuguese Literature, through the creation and editing of videos. The second objective is to develop a reflection about the (re)definition of the student's role, as well as the teacher's role in its ability to be autonomous as a "teaching professional" and "curriculum manager", in this everchanging social and technological world.

It is a case study of exploratory and qualitative nature, framed in an action-critical research environment, carried out in the academic year 2017/2018 with 23 students from a $12^{\text {th }}$ grade class. It focused on the field of Literary Education, planned for Portuguese classes official program. The teacher-researcher used methodologies and innovative strategies, resorting to digital technologies, and focused on students' skills as "generation Z".
\end{abstract}

The data were collected using various techniques: i) participant observation; ii) document analysis; iii) testing; iv) and surveys, in the form of questionnaires and interviews.

Firstly, the results obtained allow to conclude that the approach to literary works, through video, enhanced autonomous, rewarding, and challenging learning: the student is, in fact, placed at the center of the teaching and learning process. It is possible to conclude that the investigation has promoted the fullness education success of the students by: the progress in terms of both written and oral expression, cultural enrichment, technological skills, critical thinking, the ability of working in team, autonomy, time management, creativity, aesthetics, and the results obtained in summative tests as well as in national examinations. In other words, the methodology and the strategies harmoniously reconciled the formal curriculum and the competencies set out in the "Perfil dos Alunos à Saída da Escolaridade Obrigatória" (Profile of Students on Leaving Mandatory Education).

Secondly, the study shows the importance of the role of the teacher, as a teaching professional, able to manage the curriculum autonomously, as conferred by the Teaching Career Statute, as well as it proves that the teacher is capable to practice his art, in a permanent self-reflection on his praxis.

Keywords: Video, Autonomy, Educational Success, Digital Technology.

\section{INTRODUCTION}

The School is living a dilemma between the centuries-old tradition of the exclusivity of the transmission and the certification of socially important knowledge and the contemporary idea that this knowledge is available to anyone on the Internet. On the one hand, it is tried to define it as an essential reference for the society since the society is, for now, the sole institution that certifies the knowledge acquired by the individuals. Socially, it is known that the role of training citizens belongs to the School since it disseminates the knowledge needed for the society to work. On the other hand, the School is no longer the sole owner of the knowledge given that the society has developed itself in a pace that the School could not keep up with. The society has developed technological tools that have the capacity to produce information that can be converted into knowledge. The information circulates in the most powerful technological means ever created by humans. That is why we talk about Information Society, Network Society [1] or even Cyberspace [2] - a connected world where, according to George Siemens [3], "the technology has reorganized the way we live, the way we communicate and the way we learn". In this universe, the teenagers are moving completely freely thanks to the computer and the smartphone, their loyal and inseparable friend: the youth uses smartphones in an incredible intuitive way. 
In this context, firstly, the research aims to demonstrate how we can motivate the students to fully read the literary works included of the $12^{\text {th }}$ grade Portuguese language subject curricula, in the domain of the Literary Education. Secondly, it aims to awaken on young people the interest in reading, the joy of learning and of overcoming themselves. The qualitative study is held on a critical research-action environment [4], since the researcher is present on the action field thanks to her proximity and interaction with the participants, with the goal of trying to solve problems and improve her pedagogical practices.

\section{METHODOLOGY}

\subsection{Type of study}

Considering the challenges of the technological and global society of the $21^{\text {st }}$ century, the educational trends, both at national and international level, point to pedagogical methodologies and strategies that foster an autonomous and creative learning and that are centered on th9e learner's involvement [5] [6], and that empower the competences registered in the "Perfil dos Alunos à Saída da Escolaridade Obrigatória" [7]. Based on this understanding, the students, organized in groups, were requested to produce videos for the purpose of presenting the works developed on the literary work included on the Portuguese language subject curricula. This study aims to show that video creation/direction/ production and editing allows i) to motivate the students and awaken in them the interest in reading and in the Portuguese language subject; ii) to acquire the competences referred to in the "Perfil dos Alunos" [7]; iii) to accomplish educational success on both internal evaluation (school) and external evaluation (national examinations).

Therefore, we present a study sustained on innovative pedagogical practices that aim to empower an autonomous and creative learning through the video production by students with the purpose of motivating them to read the literary works in a multifaceted way and of promoting the educational success. The data collection is based on the observation techniques of the participant, on documental analysis, knowledge testing, and inquiries, as detailed below.

This work aims as well to reflect upon the (re)definition of the teacher's role in so far as he/she is challenged to change his/her perspectives regarding the teaching-learning process, the technological evolution of the society, and the need to adopt the role of a learning guide, a facilitator and an intermediary. In his/her quality of "agent teacher" [6], he/she is called to become the curricula manager and reflective teacher [4] who permanently (re)evaluates his/hers practice so the student improves his/her learning. The teacher-researcher kept a field journal where she systematically wrote down notes and considerations.

\subsection{Research setting and participants}

Since the research aims to collect and analyze data related to a pedagogical practice, the setting is the one of a Portuguese Public High School located in the North of Portugal. The participants attend the 2017/2018 academic year, integrating a $12^{\text {th }}$ grade class on the domain of Sciences and Technology, which class consisted of 23 students, 2 boys and 21 girls, with ages between 16-17 years old. The study was conducted on the Portuguese language subject. The classroom was organized in way to gather the participants in working groups, formed by the teacher.

\subsection{Data collection strategies}

The data collection uses the following techniques: students in action participant observation (where field notes are recorded in a journal); document analysis (the students' videos); knowledge testing (internal tests and national examinations); and surveys (by means of questionnaires and interviews).

\subsubsection{Participant observation}

The study uses the participant observation in so far as the teacher (who is also the researcher) interacts daily with the participant students and takes field notes. The research formally analyzes the day to day work of the class while they are performing their tasks inside and outside of the classroom, from the perspective of a ubiquitous learning [8]. This process took place during the whole academic year. This way, the teacher-researcher was able to observe and register behaviors, actions, perceptions, or considerations. When needed, she would guide and perform the adequate 
adjustments and changes to the pedagogical strategies according to her perceptions and considerations about the development of the teaching and learning process.

\subsubsection{Document analysis}

Regarding the production and editing of the videos, the participants were distributed in six (6) groups that worked on and presented four contents within the literature field of the Portuguese language subject curricula. The produced videos cover the following works: O Livro do Desassossego written by Bernardo Soares; Mensagem by Fernando Pessoa; the $20^{\text {th }}$ century tales Sempre é uma companhia by Manuel da Fonseca; George by Maria Judite de Carvalho; Famílias desavindas by Mário de Carvalho; and O Ano da Morte de Ricardo Reis by José Saramago. In total, throughout the academic year, the participants have produced 21 videos during 7 to 30 minutes. To analyze these videos, a grid was used, adapted from another work developed during the 2007/2008 academic year [9].

\subsubsection{Knowledge testing}

The written evaluation summative tests obeyed to the usual format, according to the model and ponderation of the exams, used on external evaluation until July 2017. Though trying to innovate her pedagogical action, the teacher-researcher has never lost sight from one of the goals to be accomplished on the $12^{\text {th }}$ grade: perform the national examination. And this due to caution reasons. The tests were carried out outside the weekly schedule, during 120 minutes with no tolerance time, in order to work as a practice for the exam and with a time period that allows the students to have a good performance. The same conditions were followed in the general written test, collaboratively designed by the five $12^{\text {th }}$ grade teachers, and the test was performed in the end of the year by the 10 classes of the school.

The teacher-researcher would always offer a word of positive reinforcement and appreciation of the students' gradual efforts and progress, mainly of those with lower evaluations in the previous years. It is important to highlight the importance of effectively valuing the engagement and progress of the classifications that reflect the effort of the students. The teacher must work towards the effective success and should not refrain from rewarding the students with good grades, translating into fair numbers the students' effort and progress. Therefore, the teacher must be able to measure what is so hard to measure: the human dimension. If the society is also formed by numbers, the teacher must have the capacity to use that instrument to reward the effort made by the student. What kind of student would continue to make an effort if not rewarded? There is the need for coherence so the student sees and gives meaning to his/her daily work, and feels that his/her potential is valued [10] so he/she feels motivated and encouraged to continue to make efforts. Also, this is a way of stimulating the interest and enthusiasm towards learning and towards the school. In a good way, this is a vicious circle: the more motivated the student is to learn, the more motivated he/she will be to engage himself/herself, and, therefore, the more he/she will learn. In this perspective, the works developed in video format were seen and evaluated in the different domains of the Portuguese language subject literary education, grammar in written expression, oral expression, reading - in so far as the student had to read while researching; had to write while creating the scripts used as the base of the videos; and had to speak, pronouncing a quality speech as checked by the teacher-researcher and her colleagues during the collaborative evaluation. It is important to highlight that this evaluation equals to $35 \%$ of the evaluation criteria used by the school group: $25 \%$ for speaking and $10 \%$ for attitudes, values and skills. This was a conscious and wise evaluation where all the facets of the student' performance were tried to be contemplated thanks to the production of the videos. The written summative tests corresponded to $65 \%$ of the evaluation, according to the same criteria used during the 2017/2018 academic year.

Regarding the formative evaluation, the teacher-researcher handed tests of the previous academic years as a recap of the program contents of the $10^{\text {th }}$ and $11^{\text {th }}$ grade, and has always asked for a conscious and reflexive analysis of all of the delivered summative tests' corrections. These considerations were introduced in Padlet, being this a space for collaborative and ubiquitous sharing. This practice led the students to having a greater conscience of their mistakes, aiming to correct them. Besides, when delivering and correcting the tests, the teacher mentioned the most common mistakes and explained them always from a perspective of error awareness, in the sense of the self-correction [11]. 


\subsubsection{Surveys by means of questionnaires and interviews}

The data was collected using the technique of surveys by means of questionnaires and interviews. These data collection instruments were used seven months after the participants have completed high school. The intention was, firstly, to allow the students-participants to be fully integrated on the dynamics of the higher education academic reality, and, secondly, to allow some distancing from the pedagogical methodologies and strategies used on the $12^{\text {th }}$ grade. The questionnaires were designed from scratch, especially for this study, using the Google forms tool.

In a fist phase, on January 22, 2019, we performed an inquiry by means of a questionnaire and shared its link on the closed group created on the social network Facebook, that served as a virtual classroom during the academic year when the research was made. Given the students-participants are no longer in direct contact with the teacher-researcher and given the connective setting, this was considered to be the most adequate process to reach the participants. Besides its convenience, this option preserved the confidentiality, the anonymity, and the voluntary aspect, giving the participants the freedom to respond or not to the questionnaire. It was also granted a greater objectivity and sincerity by the respondents, with the intent of reaching the greatest possible reliability. Furthermore, the participants were in a situation of total independence from the teacher-researcher and from the research results.

Based on the same principles and using the same tool (Google forms), it was designed another questionnaire directed to the parents/guardians, which was shared on the same virtual space of the students.

In a second phase, it was used another inquiry instrument, the interview. We have interviewed a few participants using Messenger, with the intent of knowing the reasons why they have repeated or not the Portuguese language subject national examination on the second round. The respondents were the 7 participants that, though having had a positive result, wanted to retake the exam. The 3 participants that had the lowest classifications of the class on the national examination and that opted to not trying to improve their results were also consulted. It is important to mention that no one of the 7 students that repeated the exam needed the Portuguese language subject as admission exam for higher education.

\subsection{Pedagogical intervention}

As education professional, reflexive and not passive [4], the teacher-researcher has inspired herself on the goals of different legal documents and guiding documents of the school group where she teaches in order to find compelling grounds for the methodological project and pedagogical strategies adopted. They are: "Estatuto da Carreira Docente dos Educadores de Infância e dos Professores dos Ensinos Básico e Secundário" (Status of the Teaching Career of Kindergarten, Primary, and Secondary Education Teachers); "Programa e Metas Curriculares de Português" (Curricula and Curricular Goals of the Portuguese language subject) directed to the secondary education, updated version of January 2014; "Perfil dos Alunos à Saída da Escolaridade Obrigatória" (Profile of Students on Leaving Mandatory Education) [7]; and "Projeto Educativo do Agrupamento de Escolas" (Educational Project of the School Group). The guiding principles founded in the "Perfil dos Alunos à Saída da Escolaridade Obrigatória" (Profile of Students on Leaving Mandatory Education) [7] are ruled by humanistic values that promote the student's valorization in several ways, whether as a human person and whether as a future citizen that will integrate a technologically developed democratic and participative society where, as an adult, the student will have an interventive role and will be aware of his/her rights and duties towards other human beings and the Nature.

The underlying purposes of these competences aim at equipping the student with useful tools and at preparing him/her for a full citizenship so he/she can later perform his/her role of responsible and selfaware citizen while interacting with others and with the environment.

As a guidance to the teacher, the mentioned Curricula and Goals, which are to be met, have consolidated the pedagogical acting in which the encouraging and innovative pedagogical practices were combined through the reorganization of the classroom space and the using of digital tools, (new) technologies, and the mobile devices of the students, from a perspective of BYOD (Bring Your Own Device). For that, the students were organized in groups around the tables and used several technologies inside and outside of the classroom: the smartphone, the laptop, the virtual classroom (the Facebook closed group), the Padlet wall and several video editing software. We tried to implement strategies that leverage a form of autonomous and significative learning, where the 
traditional model based in expositive classes showed flaws in so far as the teacher's role consisted, mainly, on guiding and assigning challenging tasks that allowed, on the one hand, to meet and develop the constant learnings of the approved curricula, and on the other hand, to provide the students with learnings and competences registered on "Perfil dos Alunos" (Profile of Students) [7] through the video production. This work was developed in an autonomous and peer work environment, to which the teacher had conceived innovative learning scenarios, providing scripts with the contents to explore and the goals to meet.

Sharing the idea that the "school model we know is over" [12], the teacher-researcher was, therefore, changing the educational setting so the students have the freedom [13] to create and work in a collaborative and autonomous way [6] [10] [12]. This way, maintaining their autonomy and working with their peers, the students had the opportunity to research and select information to transform it in knowledge to be converted into a final product, a video. These productions made the students (re)use the information that resulted of their researches, and made them develop scripts and storyboards, chose a soundtrack, make every type of recording, use recording and editing software, manage conflicts and solve problems arising within their work teams, and surpassing all kinds of obstacles.

Indeed, all these steps gave place to many learnings that are unlikely and impossible to acquire in a traditional classroom setting where the teacher is at the center, delivering the student the contents already thought through and organized, and where the student's action is reduced to the act of memorizing what he/she will have to later replicate in tests. Therefore, the teacher acted as a curriculum manager, i.e., as the "agent teacher" [6], the one who reflects upon his/her practices [4], upon the students' behaviors and (in)satisfactions towards the classes and tests results; a teacher that investigates and bases himself/herself on their own pedagogical experience and on the knowledge acquired through his/her daily pedagogical practice. In this case, in a praxis sustained by a long career.

\subsubsection{Creation of a closed group on the social network Facebook and of a wall on Padlet}

In a connected and (in)formal network environment [14] [15] [3], and having in consideration the students trait of "digital natives" [16], the first step towards pedagogical and technological innovation consisted on creating a closed group on the social network Facebook. This group was used as an extension and a complement to the physical classroom, being a space of two-way and ubiquitous communication between the teacher and the students [8]. The privacy was also ensured by the fact that this was a closed group, therefore, limited to the class' students and managed by the teacherresearcher and the student that created it.

And why Facebook? According to Oliveira [17], "Facebook can be used in a productive way for the purpose of teaching-learning given the following characteristics: its general and global using; its usability, in particular, its easy use; its operability (if Facebook doesn't "load", nothing else will "load"); its communication features (chat and videocall); its constant presence on the daily lives of a huge number of people (on their computer or smartphone)." (p. 1491). Using this social network has also allowed to demystify its demonization and alert for its real dangers, contributing as well for the digital literacy.

The Padlet wall has replaced an eventual notebook or portfolio, offering several advantages: sharing assignments in network and in a collaborative way; the verification and evaluation of the assignments completed in group and/or individually; the sharing of considerations and students' self-evaluation; and the ubiquitous quick and easy access to that platform through any mobile device. This wall also allows the teacher to monitor more closely the work developed by the students, and their performance on and commitment to the proposed assignments.

The applications Kahoot and Socrative were still used to perform the formative evaluation, meaning, the collection of information to assess the progress for the teacher and the student. These applications also allow to offer the students a quality feedback, being this a close and tailored way of teaching.

In the beginning of the academic year, the teacher-researcher tried to introduce the class to the autonomous and collaborative work, given that the most part of the students had never worked with this methodology. To do this, the working groups were given poems by Fernando Pessoa (himself). The texts were analyzed and discussed in group and in the classroom by the students and under the teacher's supervision, who walked through all the groups to support them, to observe their progress and commitment and, mainly, their capacity to understand the poetic texts without the usual help of the teacher. 
So the students could engage in a self-centered learning, we wanted each group to read the texts in a collaborative and contributed way, using or not the manual or the Internet, freely using their smartphones to research the texts, the meaning of unknown words, the biographies of the authors and other information. The teacher walked through the groups to support or guide them, as necessary. We tried as much as possible that the students made a reading effort based on their sensitive capacity and on discussing the texts with their peers. In order to support the students on creating videograms, the teacher provided a few materials related to film directing.

There was always the intention of offering dynamic and exciting classes to the students, where the teacher's voice was not the only one heard. We held discussions about the given texts or audio presentations (lectures) so the students' voice and work were always on the center of the learning.

\subsubsection{Autonomous video creation and editing}

It is important to highlight that until reaching the $12^{\text {th }}$ grade, the grade being studied, the participants were subject to a traditional teaching methodology, where the teacher is at the center of the teachinglearning process, and the students passively receive directed classes and the contents are presented completely thought through, digested and conveyed by the teacher. As a matter of adaption, the teacher-researcher had been progressively giving autonomy to the students until they were able to direct videos in a full autonomy setting, where they had carte blanche, i.e., freedom [humanistic value of the "Perfil dos Alunos" (Profile of Students)] [7] to organize and select the collected information and create their own videos. We can consider this a real innovation since this was something completely new for these students.

\section{RESULTS}

In this section, we have summarized the analysis of the data collected in the survey phase by means of a questionnaire that was submitted to the participants of the study as well as their parents/guardians seven months after the experiment. We also present the analysis of the videos created by the students and their classifications with regards to both internal evaluation (in the school) and external evaluation (national examinations). We also present the students interviews where the national examination was discussed. Finally, we explain the considerations regarding the participant observation.

The feeling of insecurity is normal when we have to think and select the acquired knowledge in a free and autonomous way, and when we have to manage ourselves, along with the fact that the assignments were of unprecedent character (a video) to the students. Though the teacher had provided a script so the students could perform the tasks, the students had to transfer texts and ideas from literary texts into an audiovisual format, as they were obliged to develop competences never asked for or developed in a school setting before.

With the survey by means of a questionnaire we tried to know the difficulties felt during the creation of the first, second, and last video. In the first assignment, the biggest obstacle was the creation and editing of the video (13/22 responses) followed by the coordination of the working group's elements ( $8 / 22$ responses). By the end of the year, it was the creativity that represented the biggest concern (8/22 responses). The time management continued to be a big constraint (7/22 responses), but 5/22 responders say they have not found any difficulty. The main difficulties identified refer to the competences listed in the "Perfil dos Alunos à Saída da Escolaridade" (Profile of Students on Leaving Mandatory Education), i.e., time management, group members' management, technological and digital knowledge (video editing), problem and conflict solving, autonomy, and creativity. Throughout the year, we could notice that these difficulties were being surpassed having even completely disappear in the case of some students $(5 / 22)$

When asked about the impact of the competences and learning acquired on the $12^{\text {th }}$ grade (the students responded seven months after the experiment took place, being already in the university), 20/22 participants considered that the Portuguese language classes were fundamental for their integration in the academic world.

We obtained 9 responses to the inquiry sent to the parents/guardians. It is important to highlight that no parent/guardian showed discontentment or disagreement regarding the teacher's methodology. On the contrary, during the class council meetings, the parents' representatives have always showed satisfaction with regards to the students' unmatched engagement and motivation towards the Portuguese language subject. 
When it directly comes to the teaching of the Portuguese language, the students have improved their written and oral expression, have had better classifications on the summative tests and showed a great motivation and interest in all of the assignments. Comparing to the previous year, some students have raised their classifications in 2 to 4,5 points. Finally, in the national examinations, the average classification of the class was of 13,91 points against the school's average classification of 10,7 points and the national average classification of 11 points.

\section{CONCLUSIONS}

Though this is a case study, we prove that it is possible to conciliate the pedagogical innovation, using digital technologies, with the observance of the curricula contents. We put to practice a methodology that encouraged the student's autonomy and that required him/her to use his/her creativity, combined with the use of and compliance with the $12^{\text {th }}$ grade Portuguese language subject approved goals and curricula. We also prove that an innovative practice does not prevent the students from accomplishing full success, obtaining also good or very good results whether in the internal/continuous evaluation or in the external evaluation. The fear of innovating, which is understandable and rightful, is based precisely on the fear of not complying with the curricular goals and generated by the belief that there is a risk of having negative consequences on the national examinations. This is, therefore, a myth. Actually, a close observation tells us that the fact that the teacher exposes (and teaches all the contents) doesn't mean that the student, as listener and passive actor, retains or masters those contents. This is the biggest misconception that has been representing one of the major obstacles to the pedagogical change. In effect, it is proven that with a stimulating and defying learning, centered on the active student and aiming at achieving a holistic view, not neglecting its human and affective dimension and emotional aspects, the student can reach educational success and personal fulfillment. This is to say that the focus is "to learn", "to learn to know", "to learn to do", "to learn to live together and to live with each other", and "to learn to be" ["Perfil dos Alunos" (Profile of Students), 2017, p. 5] [7], and this is what has inspired the teacher-researcher to go through with her action. It was intended that the students met goals like: i) autonomy; ii) sense of freedom and of responsibility; iii) critical awareness; iv) learning as a whole and as something contextualized and not fragmented; v) humanism as a immaterial legacy at both historical and linguistic level, on which our identity as a nation in relation with the world is based on; vii) problem solving with the peers; viii) creativity through the creation of audiovisual products, the video or vodcasts in so far as the videos were shared on the Internet through the social network Facebook in the class' group, in a first moment, and later on the school group's Facebook page, being available to everyone with Internet access around the world.

The choice of creating a video as a strategy is due to the fact that the production of the audiovisual works entails a deep exercise and effort from the student's side, on the one hand, regarding the contents and the resulting reading of the literary texts/works, and on the other hand, regarding himself/herself since he/she had to handle the technologies and the art of creating a narrative to represent/present the contents suggested on the innovative learning scenario conceived by the teacher. According to Oliveira [9], the use of "audiovisual podcasting, directed and produced by the students" happens in the whole world since 2004. The audiovideography as a means of expression, leverages an attractive and captivating learning that allows the student to use the self-media technologies [18]. Like this, the student is given the opportunity to go from spectator to producer, being able to develop his/her autonomy, critical awareness, and creativity [19].

The study reflects as well upon the redefinition of the teacher's role in so far as he/she is challenged to change his/her perspectives regarding the teaching-learning method, having now a role of learner guide, facilitator and intermediary, keeping also in mind the technological evolution happening in the society. On the other hand, in his/her quality of "agent teacher" [6] he/she is called to become the curriculum manager, and, in his/her quality of reflective teacher [4] he/she needs to reflect upon and re(evaluate) his/her practice so the student can improve his/her learning.

We conclude also by saying that, in the setting of a transforming school, the teacher needs to understand that he/she is a fundamental part on the gear that is the whole teaching and learning process. And this because it is the teacher who is the link between the approved curricula and its implementation on the student's side; the intermediary between learning and knowledge; the promoter of the humanization and the (social) integration of the student on his/her quest to conquer its adolescent freedom and, perhaps, a certain vision of the world; and also because the teacher is the one who can make a difference in implementing the approved curricula. 


\section{ACKNOWLEDGEMENTS}

This work is funded by CIEd - Research Centre on Education, Institute of Education, University of Minho, projects UIDB/01661/2020 and UIDP/01661/2020, through national funds of FCT/MCTES-PT.

\section{REFERENCES}

[1] M. Castells, The Internet Galaxy: Reflections on the Internet, Business and Society. England, Oxford: Oxford University Press, 2001.

[2] P. Lévy, "Cibercultura e Inteligência Coletiva". Roda Viva, 2001. Retrieved mai 28, 2018 from https://www.youtube.com/watch?v=DzfKr2nUj8k.

[3] G. Siemens, "Conectivismo", 2015. Retrieved mai 25, 2018, from https://www.youtube.com/watch?v=MJDyX7_J51M.

[4] J.L. Kincheloe, "Os Objetivos da Investigação Crítica: O Conceito de Racionalidade Instrumental". In J. M. Paraskeva, \& L. R. Oliveira (Orgs.) Currículo e Tecnologia Educativa. Volume 2. Mangualde:Edições Pedago. Pp.47-86, 2008.

[5] L.S. Vygotsky, Mind in society: The development of higher psychological processes. Cambridge, MA: Harvard University Press, 1978.

[6] M.A. Flores, O papel do professor no desenvolvimento curricular, in a Indução no ensino: desafios e constrangimentos. Lisboa IIE, 2000. Photocopied document, without pagination.

[7] Despacho n. ${ }^{\circ}$ 6478/2017, de 26 de julho, Perfil dos Alunos à Saída da Escolaridade Obrigatória (2017). Lisboa: Ministério da Educação e da Ciência/Direção-Geral da Educação. Retrieved sepetember 20, 2017, from

https://dge.mec.pt/sites/default/files/Curriculo/Projeto_Autonomia_e_Flexibilidade/perfil_dos_alun os.pdf.

[8] L. Santaella, Desafios da ubiquidade para a educação. Campinas-SP: Revista trimestral da Universidade Estadual de Campinas, pp. 19-28. número 9 | abril-junho de 2013. Retrieved november 10, 2017, from https://www.revistaensinosuperior.gr.unicamp.br/edicoesanteriores/2013-07-01\%2000:00:00.

[9] L.R. Oliveira, "Podcasting: vídeo para aprender e para pensar a identidade". In A. A. A. Carvalho (Org.) Podcasts para ensinar e aprender em contexto. Santo Tirso: De Facto Editores. Pp. 266288, 2010.

[10] M.C. Roldão, Currículo e Gestão das Aprendizagens: As Palavras e As Práticas. Centro Integrado de Formação de Professor, Universidade de Aveiro, 2000.

[11] P.M. Silva, "O obsoleto modelo classificativo do ensino atual". Atas do I Congresso Internacional de Avaliação das Aprendizagens e Sucesso Escolar, pp. 31-35, 17-18 november 2017.

[12] A. Nóvoa, "Desafio do Trabalho e Formação Docentes no século XXI", 2017. Novo Hamburgo, Brasil, 2017. Retrieved january 10, 2018 from https://www.youtube.com/watch?v=sYizAm-j1rM.

[13] P. Freire, Uma Educação para a Liberdade. Coleção Textos Marginais. Porto: José M.C.S. Ribeiro, 1973.

[14] M. Castells, "Comunicação e Poder em Rede". Universidade Diego Portales, 2010. Retrieved mai 30, 2018, from https://www.youtube.com/watch?v=IPLg73I11A4\&feature=youtube

[15] S. Downes, "La Educación permanente, Aprendizaje formal, informal y no formal". Encuentro Internacional de Educación, 2013. Caracas. Retrieved mai 28, 2018, from https://www.youtube.com/watch?v=sCefaxfCJho

[16] M. Prensky, Digital Natives, Digital Immigrants. On the Horizon, Vol. 9 No. 5, October 2001. Disponível em http://pt.scribd.com/doc/9799/Prensky-Digital-Natives-Digital-Immigrants-Part1, consultado em 10 de junho de 2018.

[17] L.R. Oliveira, "Mediação docente e distância transacional: uso do Facebook num mestrado em regime misto (b-learning)". Revista e Curriculum, v. 14, n. 4, pp. 1484-1498, 2016. 
[18] J. Cloutier, A era de EMEREC ou a comunicação áudio-scripto-visual na hora do self media. Lisboa: Ministério da Educação e Investigação Científica - Instituto de Tecnologia Educativa, 1975.

[19] M.J. Ferreira \& L.R. Oliveira, "Audiovideografia e construção de identidades: um estudo de caso com alunos do $6^{\circ}$ ano de escolaridade". In B. D. Silva e A. B. Lozano (Eds.) Atas do X Congresso Galaico-Português de Psicopedagogia. Braga: Universidade do Minho, pp. 5526-5534, 2009. 